\title{
Inhibition of Tau Phosphorylation as a Potential Strategy in Treatment of Parkinson's Disease
}

\author{
Wang Wenya \\ School of Pharmaceutical Sciences, Southern Medical University
}

China

\section{Introduction}

At present, Parkinson's disease (PD) has become the third most common neuropathy following cerebrovascular diseases and epilepsy, and is the second most common neurodegenerative disease after Alzheimer's disease (AD). There is growing evidence that neuronal apoptosis plays a key role in the mechanism in PD, AD and other neurodegenerative diseases [Mattson, 2000; Yuan \& Yankner, 2000]. Therefore, regulating neuronal apoptosis signaling pathway will provide a theoretical basis to reveal the mechanism of neuronal apoptosis; and on the basis of research, development of antineuronal apoptosis drugs to selectively interfere with critical target of apoptosis signaling pathway would be an important means in prevention of neurodegenerative diseases effectively.

Although subject to intensive research, the etiology of PD is still enigmatic, which in turn has hindered the development of effective treatment. Today, PD treatment is basically symptomatic, and no neuroprotective therapies are available. The current therapy for PD mainly aims at replacing the lost neurotransmitters. The signs and symptoms of PD can be alleviated with drugs that enhance dopamine function, among which, levodopa is considered the most effective one. The most severe shortcoming of levodopa treatment is that it fails to alter the progression of PD. Patients with advanced PD may develop a variety of motor complications associated with levodopa therapy, such as switching phenomena and dyskinesia [Rylander et al., 2010]. More disappointing is the therapeutic effect of levodopa weakens after about two years (Marsden \& Parkes, 1977). Therefore, there is still an urgent need of finding more beneficial treatment strategy for the disease. Here, we proposed a neuroprotective drugs to effectively control the course of PD: it can inhibit substantia nigra dopaminergic neurons from "primary" progressive loss, so as to achieve the purpose of effective treatment of Parkinson's Disease.

\section{Inhibition of tau phosphorylation as a potential strategy in treating PD}

Dopamine neurons have a strong ability of physiological compensation before the disease is clinically evident. Generally, the disease become clinically evident (decompensated state) when the dopamine neuron loss is sufficiently severe (greater than $75 \%$ of nigrostriatal dopamine neurons) [Lloyd, 1977]. It is well known that programmed cell death (apoptosis) plays a key role in the neurodegenerative processes in PD [Büeler, 2010; Nagatsu \& Sawada, 
2007]. Several intraneuronal pathways are implicated in N-methyl-4-phenyl-1, 2, 3, 6tetrahydropyridine (MPTP) -induced neuronal apoptosis [Chung et al., 2010; Ethell \& Fei, 2009; Karunakaran et al., 2008; Saporito et al., 2010]. These include c-Jun N-terminal kinases (JNK) signaling, p53 activation, cell cycle re-activation, Glycogen synthase kinase-3 (GSK3)/Tau signaling pathway, signaling through bcl-2 family proteins and so on. The neurotoxin MPTP is converted in the brain into 1-methyl-4-phenylpyridinium iodide [MPP $(+)$ ] by the enzyme monoamine oxidase B (MAO-B). MPP $(+)$ is a selective inhibitor of mitochondrial complex I and is widely used in rodent and cell models to elicit neurochemical

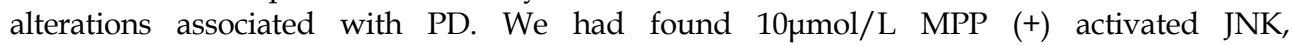
phosphorylated c-Jun and induced neuronal apoptosis. It decreased the number of tyrosine hydroxylase (TH) immunopositive cells and reduced cytoplasmic volume. SP600125 [Bennet et al., 2001], the specific inhibitor of JNK protected dopaminergic neurons and increased the number of $\mathrm{TH}$ immunopositive cells via inhibiting c-Jun phosphorylation. These results indicated that SP600125 inhibited the activation of JNK and therefore protected dopaminergic mesencephalic neurons from apoptosis induced by $\mathrm{MPP}(+)$, which suggested that JNK might be a new target of influencing neuronal apoptosis [Wang et al., 2004]. Therefore, we had first proposed a new strategy for PD treatment, which is using a specific inhibitor of JNK. Of course, there are a great number of "targets" to interfere with nigral dopaminergic neuronal apoptosis, such as GSK-3 $\beta$, also named as Tau protein kinase I (TPK I).

\subsection{The tau protein}

Tau is a low molecular weight component of cytoskeletal structures. It is one of several types of microtubule-associated proteins (MAPs) which regulate the assembly and stability of microtubule networks. Although microtubule networks exist in all kinds of animal and plant cells, the mRNAs encoding tau proteins are expressed predominantly in neurons, where these tau proteins are localized mostly to axons [Higuchi et al., 2002]. They are abundant in neurons in the central nervous system and are less common elsewhere. This unique feature suggests that Tau may have neuron-specific functions. In a healthy person, tau protein interacts with a compound called tubulin to strengthen the neural tubes in the axons of neurons. The neural tubes essentially act like train tracks for signals to pass along the axon. Disruption in the level of tau protein can lead to instability in the neural tubes, which makes it difficult for neurons to pass signals along [Kowall \& Kosik, 1987]. When tau proteins are defective, and no longer stabilize microtubules properly, they can result in dementias, such as Alzheimer's disease [Sergeant et al., 2008].

\subsection{Normal functions of tau phosphorylation}

Protein phosphorylation is widely used to regulate cellular processes, because it can affect binding between two proteins. Phosphorylation is a process that adds a phosphate group to a protein, particularly on the amino acid serine, threonine or tyrosine. For the Tau protein, its association with microtubules is inhibited if certain residues in its microtubule binding domain are phosphorylated [Gendron \& Petrucelli, 2009]. The phosphorylation of tau plays a physiological role in regulating the affinity of tau for microtubules. Though less well studied, phosphorylation also regulates the binding of tau to signaling molecules and could thus influence tau-mediated signaling [Reynolds et al., 2008]. The kinases that phosphorylate tau can be divided into two major groups, according to motif specificity: proline-directed protein kinases (PDPK) and non-proline-directed protein kinases (non- 
PDPK). The PDPK include cyclin-dependent kinase 5 (cdk5), mitogen-activated protein kinase (MAPK), and several stress-activated protein kinases. GSK3- $\beta$ is often described as a PDPK but the proline is not always required for phosphorylation by GSK3- $\beta$.The phosphorylation of tau by these kinases inhibits the ability of tau to promote microtubule assembly and facilitates the polymerization of tau into paired helical filaments (PHFs) [Evans et al., 2000]. Among the non-PDPK are cyclic AMP-dependent protein kinase (PKA), calcium- and calmodulin-dependent protein kinase II (CaMKII), and microtubule affinity regulating kinase (MARK). Unbound tau may then be hyperphosphorylated by other kinases. In fact, the phosphorylation of tau by MARK may be a prerequisite for the action of downstream kinases, including GSK-3 $\beta$ and Cdk5 [Nishimura et al., 2004].

Recently, Tau has received great attention because mounting evidence has indicated that hyperphosphorylation of Tau is the origin of Alzheimer's disease (AD). In an AD brain, too many residues in the Tau protein are phosphorylated [Buerger et al., 2006; Schönknecht et al., 2003 ]

\subsection{Phosphorylation of tau in PD}

Hyperphosphorylation and accumulation of Tau in neurons and glial cells result in PHFs and is one of the main pathologic hallmarks in many neurodegenerative disorders such as AD and other Tauopathies [Sato et al., 2006]. Phospho-Tau (Ser396) has been found in synaptic-enriched fractions in AD frontal cortex at entorhinal/transentorhinal, limbic and neocortical stages [Muntané et al., 2008]. GSK-3 $\beta$ - immunoprecipitated sarcosyl-insoluble fractions from $\mathrm{AD}$ patients can phosphorylate recombinant Tau [Ferrer et al., 2005]. Densitometric studies show between $20 \%$ and $40 \%$ phospho-Tau (Ser396) in synaptic-enriched fractions of the frontal cortex in PD [Muntané et al., 2008]. Moreover, Tau- immunoreactive Lewy bodies (LBs) are detected in the medulla of $80 \%$ of individuals with sporadic PD or dementia with LBs, where Tau is often localized at the periphery of LBs [Ishizawa et al., 2003]. We also found MPP (+)/MPTP induced abnormal phosphorylation of Tau at Ser396 in nigra in PD models. To investigate whether Tau is phosphorylated in MPTP-treated dopaminergic neurons, we examined the histochemical localization of Tau (Ser396) phosphorylation level in SNc following treatment with MPTP. TH immunofluorescence was used to detect DA neurons. Three months old adult male $\mathrm{C}_{57}$ black mice were given MPTP at a dose of $30 \mathrm{mg} / \mathrm{kg}$ ip. once daily for 7 days. SNc slices were prepared $6 \mathrm{~h}$ after the third MPTP injection, and double-labeled with antibodies against TH and phospho-Tau (Ser396). We found that in MPTP-treated mice, nearly all TH positive cells exhibited the increased levels in phopsphoTau, whereas no loss of TH positive cells was observed. Furthermore, many TH negative cells were stained with phopspho-Tau, but the levels were unchanged between MPTP-treated and untreated mice [Wang et al., 2007]. Cell counting results showed that in MPTP-treated group the percentage of phopspho-Tau stained neurons in TH positive cells was increased to $98 \%$, while the control was just $37 \%$. These results suggest that after MPTP treatment, Tau is selectively phosphorylated in dopaminergic neurons. Similarly, Qureshi HY found that exposure of human neuroblastoma M17 cells to MPTP enhances intracellular alpha-synuclein protein level, stimulates Tau protein phosphorylation at Ser262 and induces apoptosis [Qureshi \& Paudel, 2010].

\subsection{Preventing tau phosphorylation rescued neurons}

A cdk5 inhibitory peptide (CIP) selectively inhibited p25/Cdk5 activity and suppressed the aberrant Tau phosphorylation and reduced apoptosis in cortical neurons [Zheng et al., 
2005]. In SH-SY5Y-cotransfected cells expressing a-Syn and human dopamine transporter (hDAT), both $\mathrm{LiCl}$ and TDZD-8 blocked GSK-3 $\beta$ activation in a dose-dependent manner, with concomitant decreases in hyperphosphorylation of Tau and cell death [Duka \& Sidhu, 2006; Duka et al., 2009]. A GSK-3beta specific inhibitor, L803-mt, attenuated Tau phosphorylation and rescued DA neurons from cell death in mesencephalic cultures [Chung et al., 2010]. We had reported that AR-A014418, a specific inhibitor of GSK-3 $\beta$, reduced the levels of phospho-Tau (Ser396), protected nigral neurons from apoptosis, and restored the depletion of dopamine evoked by MPTP in $\mathrm{C}_{57} \mathrm{BL} / 6 \mathrm{~N}$ mice [Wang et al.,2007].

\subsection{Two anticancer drugs dephosphorylated tau and rescued dopaminergic neurons 2.5.1 Chromomycin A3 protected cultured dopaminergic neurons from apoptosis induced by MPP(+)}

Chromomycin A3 (Fig.1.) is a glycosidic antibiotic produced at the fermentation of a strainof Streptomyces griseus. It is also called toyomycin or aburamycin. It is not only an antibacterial antibiotic, but also an antitumor antibiotic that inhibits RNA synthesis, especially in solid tumors. Chromomycin belongs to the DNA-interactive Drugs. The compound blocks macromolecule synthesis by a specific, reversible interaction with DNA in the presence of bivalent metal ions. Binding to DNA minor groove mediates an efficient competitive inhibition of DNA gyrase and significantly affects topoisomerase II activity [Hou et al., 2008].

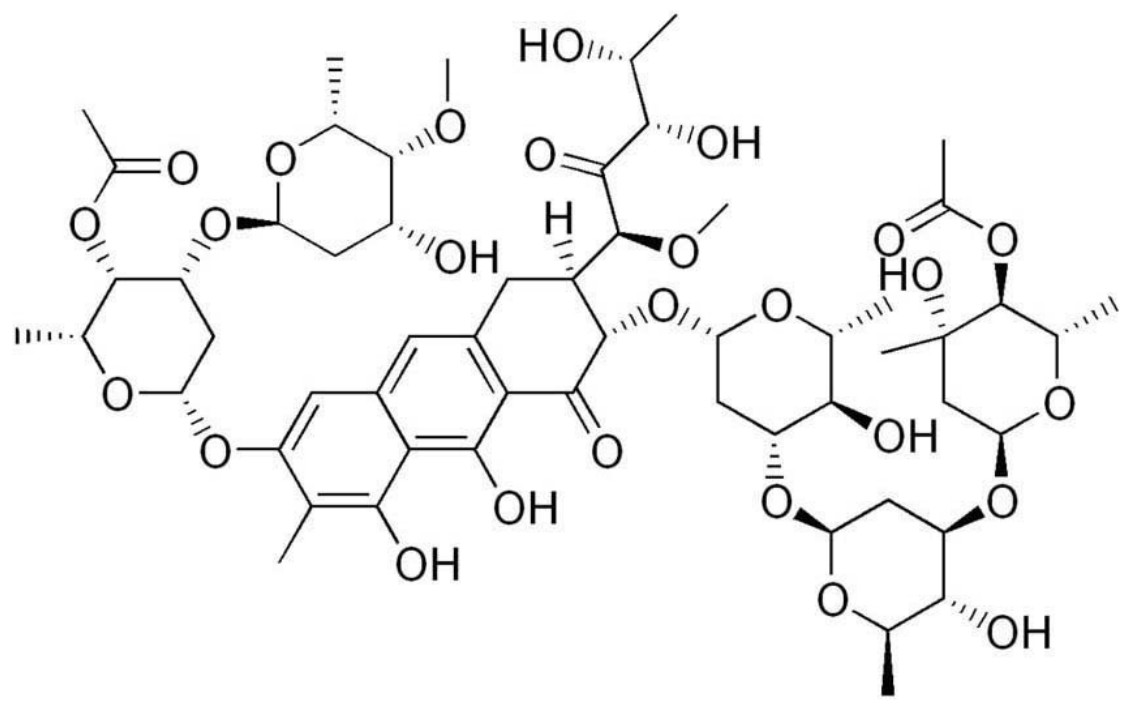

Fig. 1. Chemical structure of Chromomycin A3 [from sigmaaldrich]

Chromomycin A3 has also been shown to be a potent inhibitor of neuronal apoptosis induced by glutathione depletion-induced oxidative stress and DNA-damaging agent Camptothecin [Chatterjee et al., 2001]. Mechanistic studies suggest that chromomycin A3 antagonizes enhanced DNA binding of the transcription factors Sp1 and Sp3 to their cognate "G-C" box, induced by oxidative stress or DNA damage [Chatterjee et al., 2001]. Furthermore, by inhibiting transcription, chromomycin A3 can inhibit protein biosynthesis. 
Miller identified chromomycin A3 that inhibited NF-kappaB signaling in a NF-kappaB mediated beta-lactamase reporter gene assay. It induced caspase $3 / 7$ activity and had an inhibitory effect on cervical cancer cell growth [Miller et al., 2010]. We know that oxidative stress and elevation of intracellular calcium levels are particularly important inducers of NFkappaB activation. Activation of NF-kappaB can interrupt apoptotic biochemical cascades at relatively early steps, before mitochondrial dysfunction and oxyradical production. The available data identify NF-kappaB as an important regulator of evolutionarily conserved biochemical and molecular cascades designed to prevent cell death and promote neuronal plasticity [Mattson et al., 2000]. Together, these results suggest that chromomycin A3 may be effective agents for the treatment of neurological diseases associated with aberrant activation of apoptosis and highlight the potential use of sequence-selective DNA-binding drugs as neurological therapeutics. Last year, we reported that chromomycin A3 inhibited Tau phosphorylation at Ser396 and therefore protected dopaminergic mesencephalic neurons from apoptosis induced by MPP (+) [Wang et al., 2010].

\subsubsection{Mithramycin prevented MPP(+)-induced cultured neuronal apoptosis}

Chromomycin A3 and mithramycin (also known as MIT and plicamycin) are two DNA binding anticancer antibiotics, acting via inhibition of replication and transcription during macromolecular biosynthesis. The clinical use of chromomycin A3 is limited because of its immuno suppressive properties and greater cytotoxic effects. But mithramycin is one of the older chemotherapy drugs, which has been in use for decades. Mithramycin (Fig.2.) selectively binds to G-C-rich DNA in the presence of $\mathrm{Mg}(2+)$ or Zn (2+), inhibiting RNA and DNA polymerase action [Majee \& Chakrabarti, 1999]. It also inhibits c-myc expression and induces myeloid differentiation of HL-60 promyelocytic leukemia cells [Dutcher, 1997]. This drug is prescribed primarily in the treatment of malignant tumors of the testis. It is also prescribed in the treatment of hypercalcemia and hypercalciuria associated with cancer [Rosol \& Capen, 1987]. It is given by intravenous route only. It was discontinued as of 2000 by the manufacturer based on decreased demand.

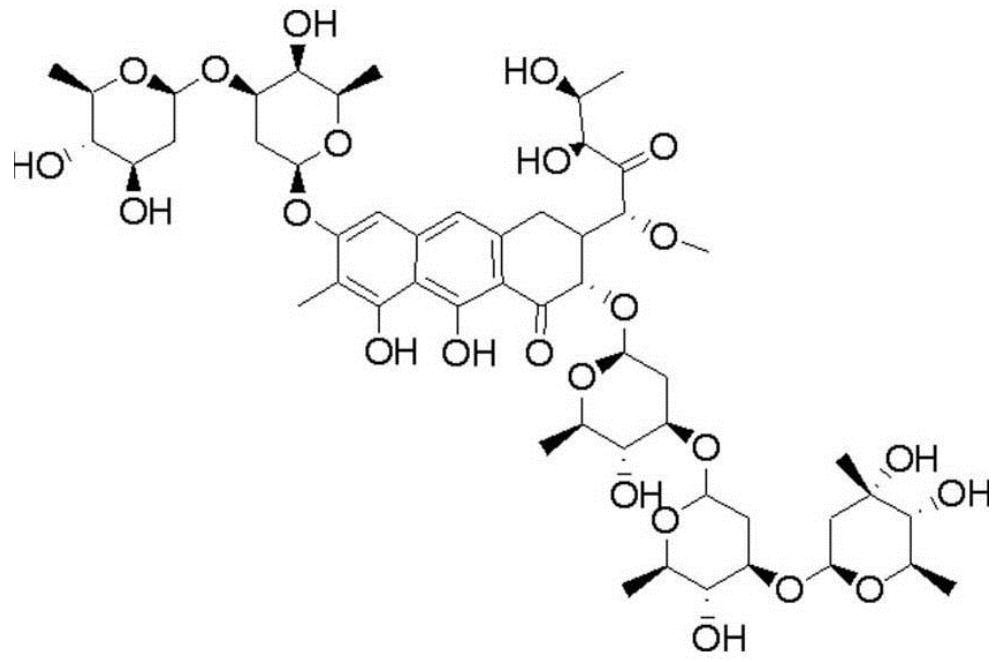

Fig. 2. Chemical structure of mithramycin [from sigmaaldrich] 
Renewed interest in mithramycin resulted in about 50 mithramycin related publications in the first half of 2010 alone. Most publications mentioned anti-cancer abilities of the compound, but other medical conditions were also referred, such as: Huntington's disease (HD) neurodegeneration [BirZeit P.A, on line]. Recent research shows that it is helpful in treating motor symptoms and prolonging life in a mouse model of HD [Ferrante et al., 2004].
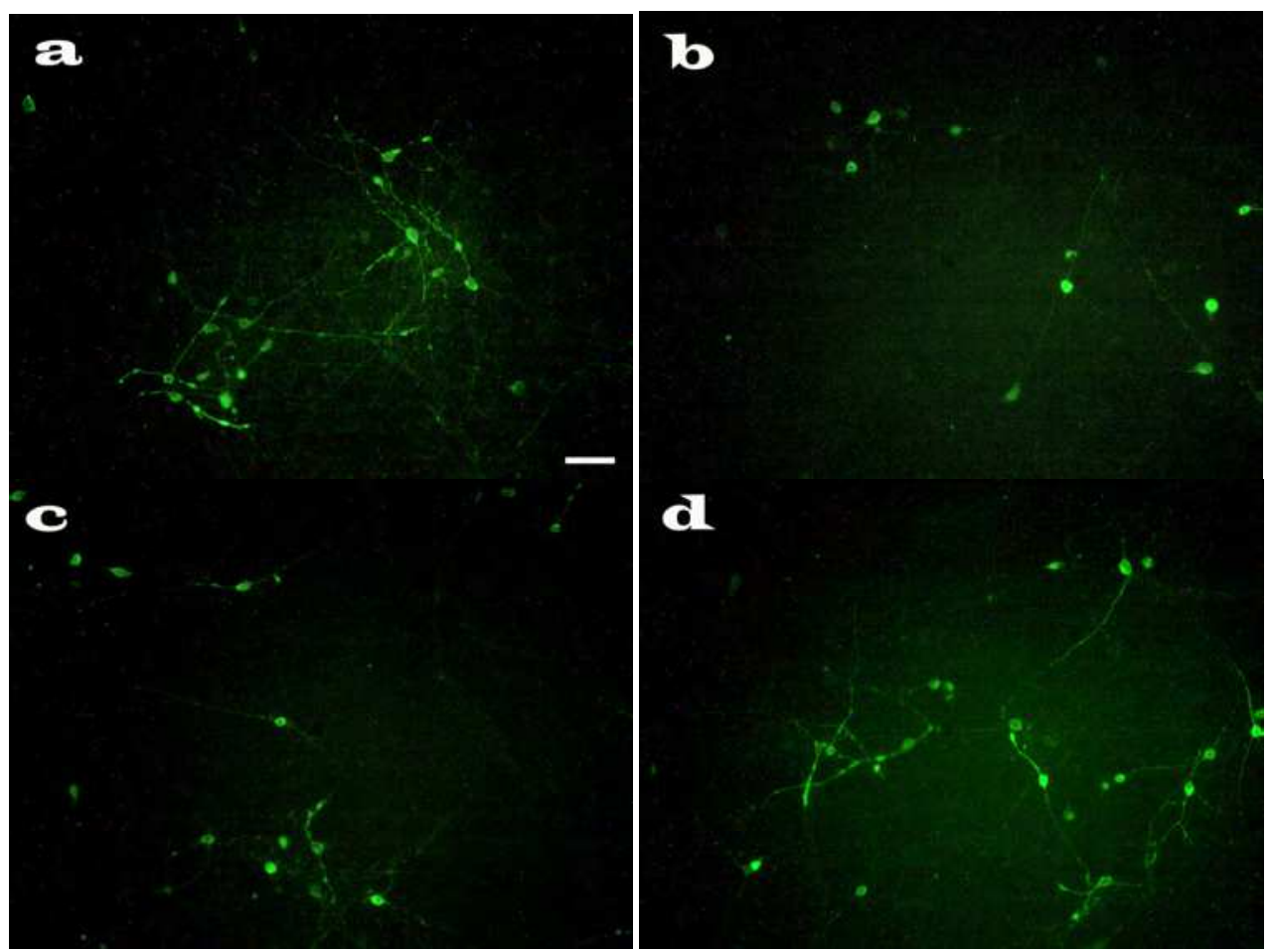

Fig. 3. Mithramycin inhibited MPP (+)-induced apoptosis in cultured dopaminergic neurons. Dopaminergic mesencephalic neurons were obtained from 14-day-old fetal rats. At DIV5, $10 \mu \mathrm{M} \mathrm{MPP}(+)$ was used to induce neuronal apoptosis for $48 \mathrm{~h}$. Specific TH-antibody was used to detect dopaminergic neurons. (a) control, Fluorescent micrograph by fluorescence microscope showing TH positive cells visualized with FITS (green); (b) $10 \mu \mathrm{M}$ $\mathrm{MPP}(+)$ decreased $\mathrm{TH}$ positive cells and reduced cytoplasmic volume; (c) $0.2 \mu \mathrm{M}$ mithramycin, and (d) $0.5 \mu \mathrm{M}$ mithramycin rescued $\mathrm{TH}$ positive cells. Scale bar $=50 \mu \mathrm{m}$.

Pharmacological treatment of a transgenic mouse model of HD (R6/2) with mithramycin extended survival by $29.1 \%$, greater than any single agent reported to date. Increased survival was accompanied by improved motor performance and markedly delayed neuropathological sequelae. Voisin screened candidate therapeutic compounds that were identified previously in cell culture/animal studies in a C. elegans HD model and found that two FDA approved drugs, lithium chloride and mithramycin, independently and in combination suppressed HD neurotoxicity [Voisine et al., 2007]. Because it is Food and Drug Administration-approved, researchers thought mithramycin is a promising drug for the 
treatment of HD. Since mithramycin has enhanced neuronal survival and neuroprotection, it may protect dopaminergic neurons. We also use cultured dopaminergic mesencephalic neurons with MPP (+) as PD cell model.
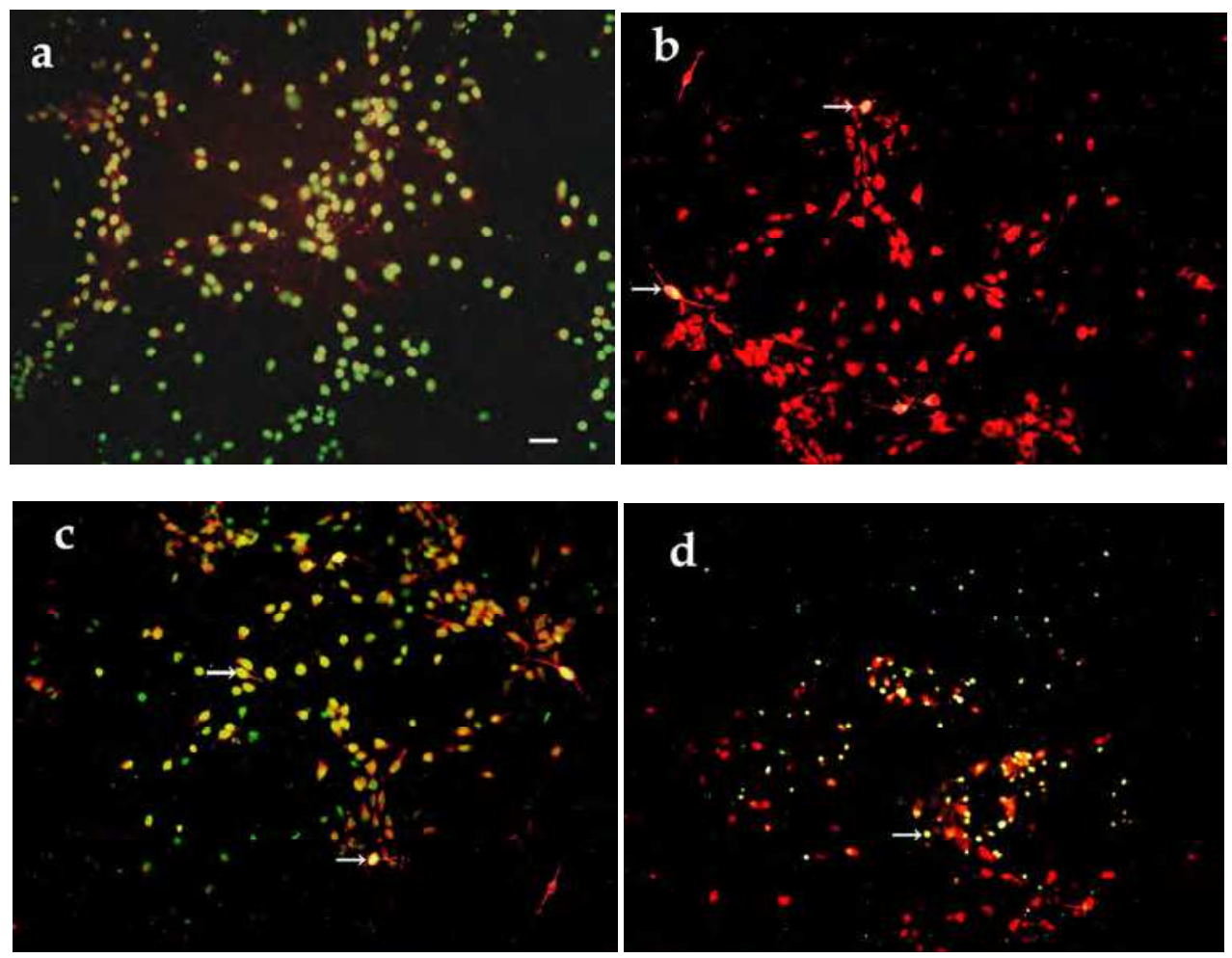

Fig. 4. TUNEL figures of inhibitory effect of mithramycin on dopaminergic neuronal apoptosis induced by MPP (+). Dopaminergic mesencephalic neurons were obtained from 14-day-old fetal rats. At DIV5, $10 \mu \mathrm{M} \mathrm{MPP}(+)$ was used to induce neuronal apoptosis for 48h. Specific TH-antibody was used to detect dopaminergic neurons. (a) Positive control. Strong TUNEL labeling showed apoptotic bodies in all kinds of cells; (b) control, vehicletreated Neurons;(c) $10 \mu \mathrm{M}$ MPP (+) induced neurons apoptosis (green) and decreased TH immunopositive cells (red). White arrow showed apoptotic dopaminergic neurons (yellow). (d) Fewer TUNEL-positive cells were shown with 1.0 $\mu \mathrm{M}$ mithramycin treatment. Scale bar $=50 \mu \mathrm{m}$. 
The embryos were removed at embryonic day 14 from pregnant Sprague-Dawley rats that had been anesthetized, then decerebrated. Ventral mesencephalon were dissected and collected. Cell suspensions prepared by mechanical trituration precoated overnight with 1 $\mathrm{mg} / \mathrm{ml}$ polyethylenimine in borate buffer, $\mathrm{pH}$ 8.3. The cells were then maintained for maturation and differentiation in DMEM/F12 culture medium. Cultures were treated at DIV1 and every three days $250 \mu \mathrm{L}$ of culture medium were replaced by medium supplemented with treatments. At DIV5, $250 \mu \mathrm{L}$ of $500 \mu \mathrm{L}$ medium were replaced by fresh medium supplemented or not with mithramycin at 200,500,1000 nM and $10 \mu \mathrm{M}$ of MPP (+) were added. After $48 \mathrm{~h}$, cells were fixed for $15 \mathrm{~min}$ with a $4 \%$ formaldehyde solution, washed three times with $500 \mu \mathrm{L}$ PBS then submitted to $\mathrm{TH}$ immunostaining to allow analysis of DA neurons. Undoubtedly, MPP (+) induced apoptosis in cultured dopaminergic mesencephalic neurons. It decreased the number of $\mathrm{TH}$ positive cells and reduced cytoplasmic volume. 200, 500 and $1000 \mathrm{nM}$ mithramycin rescued $\mathrm{TH}$ immunopositive cells from cytotoxic MPP (+) (Fig.3.). To detect DNA fragmentation, we used TUNEL. TUNEL is one of the main methods for detecting apoptotic programmed cell death. We found $1.0 \mu \mathrm{M}$ mithramycin reduced MPP (+)-caused TUNEL-positive cells (Fig.4.)

Mithramycin not only increased the number of TH immunopositive cells, but also showed protective action in a dose-dependent manner (Table 1). Interesting, mithramycin also decreased the levels of phosphorylated Tau (Fig.5).

\begin{tabular}{|c|c|}
\hline Mithramycin $(\mu \mathrm{mol} / \mathrm{L})$ & Neuronal Survival ( \% control $)$ \\
\hline 0 & $32.8 \pm 2.7$ \\
\hline 0.2 & $42.8 \pm 5.2 *$ \\
\hline 0.5 & $57.1 \pm 6.3 * *$ \\
\hline 1.0 & $65.9 \pm 7.3 * *$ \\
\hline 2.0 & $76.3 \pm 8.7 * *$ \\
\hline 5.0 & $87.3 \pm 8.4 * *$ \\
\hline
\end{tabular}

* $\mathrm{P}<0.05$, ** $\mathrm{P}<0.01$, compared with control. Control neurons were maintained in DMEM/F12 medium. Neuronal survival was calculated as percentage neuronal survival $=(\mathrm{TH}$ positive cells with different concentrations of mithramycin and $10 \mu \mathrm{M} \mathrm{MPP} \mathrm{(+)} \mathrm{for} 48 \mathrm{~h} / \mathrm{TH}$ positive cells in control medium) $\times 100$. Mean \pm S.E. ( $n=3$ independent experiments).

Table 1. Protective effect of mithramycin on dopaminergic neuronal apoptosis induced by MPP (+) in a concentration-denpendent manner. 

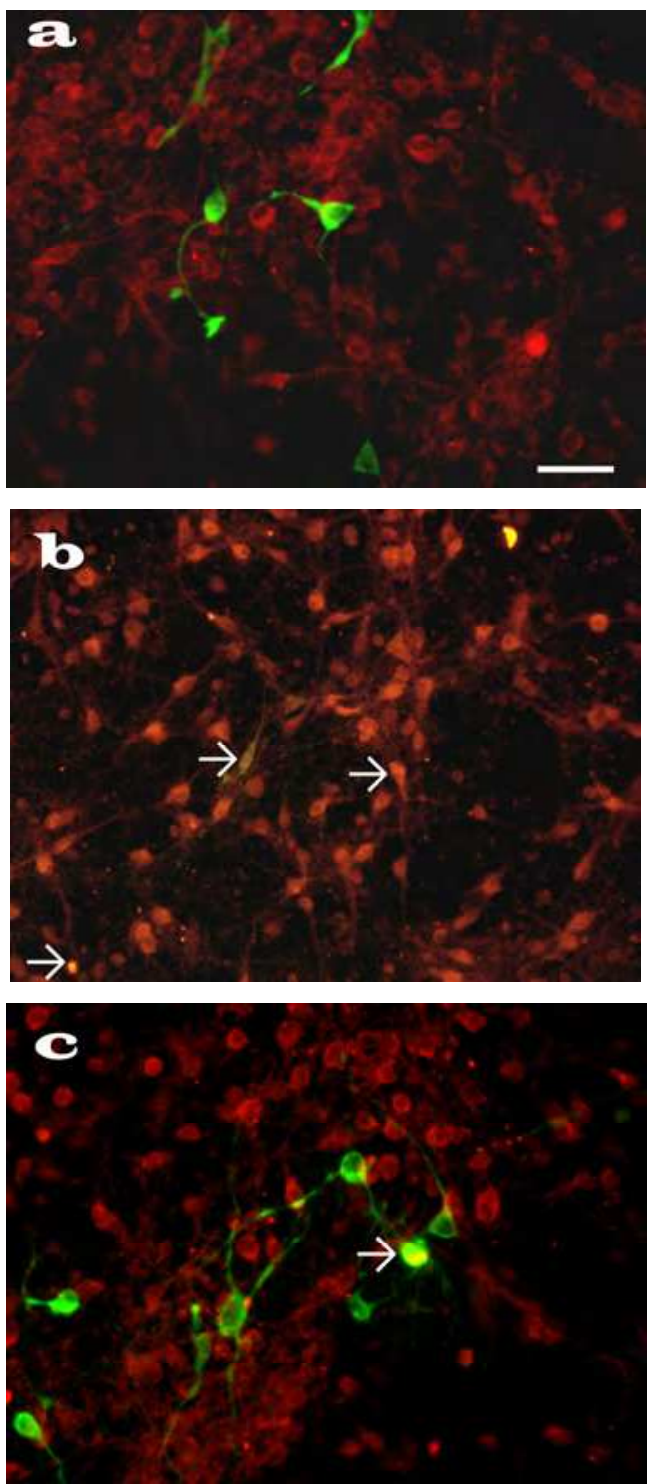

Fig. 5. Mithramycin attenuated Tau (Ser396) phosphorylation induced by MPP (+) in cultured dopaminergic neurons. Detection of p-Tau (Ser396) expression in cultured fetal dopaminergic mesencephalic neurons by immunohistochemistry was at $12 \mathrm{~h}$ after MPP (+) treatment. Specific TH-antibody was used to detect dopaminergic neurons. (a) Control, vehicle-treated cultures stained for TH (green) and phospho-Tau (Ser396) (red). (b) A culture treated with 10 $\mu \mathrm{M} \mathrm{MPP}(+)$ for $12 \mathrm{~h}$. Note more Tau (Ser396) were phosphorylated, resulting in neurons staining with salmon pink (white arrows). (c) Photomicrograph of a culture treated with 1.0 $\mu \mathrm{M}$ mithramycin. Note MPP (+) increased Tau (ser396) phosphorylation in TH positive neurons which can be prevented by mithramycin. Scale bar $=50 \mu \mathrm{m}$. 
Because mithramycin is Food and Drug Administration-approved, it may be a promising drug for the treatment of PD.

\section{Conclusions}

Among kinases involved in Tau modifications, two are the most relevant: Tau protein kinase I (TPK I) also named GSK-3 $\beta$ and Tau kinase II (TPK II), which is a complex of two subunits: cdk5 and p35 [Alejandra et al., 1999]. In addition to hyperphosphorylation of Tau, p-GSK-3 $\beta$ has the capacity to phosphorylate several transcription factors (such as Jun, Myc, HSF-1, and cAMP response element-binding protein within the nucleus) and the multifunctional protein-catenin, as well as the nerve growth factor receptor [Muntané et al., 2008]. This means different roads meat in Tau (Fig.6). As one of the numerous substrates of GSK-3 $\beta / \mathrm{cdk} 5 / \mathrm{p} 35$, Tau has limited roles. The adverse reactions of inhibiting Tau phosphorylation must be less than those of inhibiting GSK-3 $\beta$ activity. Since tau plays an important role in the pathogenesis of Parkinson's disease [Lei et al., 2010], blockade of tau by specific inhibitors may prevent or effectively slow the progression of PD and other neurodegenerative diseases. It is exciting possibility a drug will soon be developed, as there is a patent for the use of aminoindazole derivatives for the inhibition of tau phosphorylation (United States Patent 7629374). This made it possible, which is inhibiting Tau phosphorylation as a potential strategy in treating PD. On the other side, mithramycin and chromomycin A3 are both in clinical use to treat malignant neoplasms. Ultilising approved drugs in "off label" indications can speed up the delivery of new therapies.

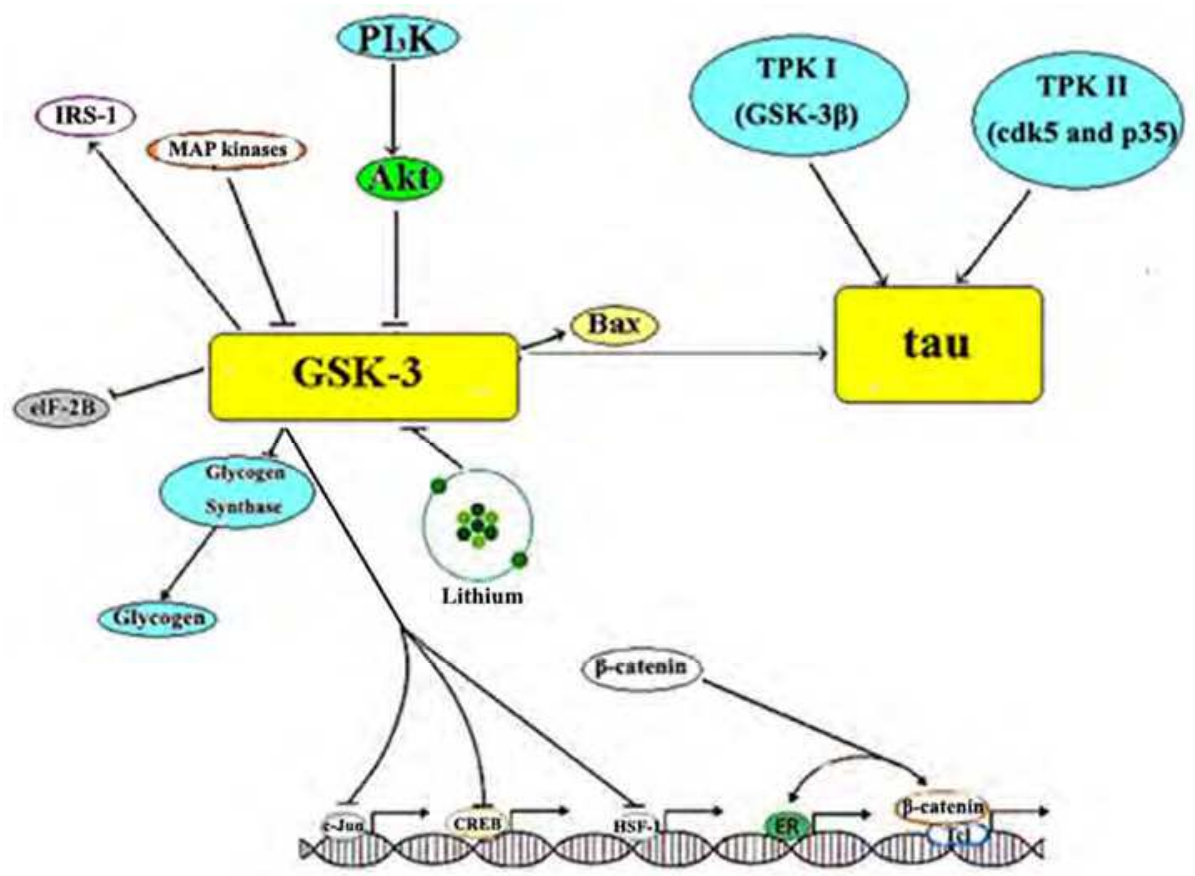

Fig. 6. The Simple diagram of GSK-3 $\beta$ /Tau signal pathways. 


\section{Acknowledgment}

This work was supported by the National Natural Science Foundation of China (Grants No.30400124 and No.81030024); the Natural Science Foundation of Guangdong Province (Grants No.93510089010000003); the funds for good middle-aged/young technology talents of Southern Medical University (Grants No. C1010098).

\section{References}

Alejandra Alvarez, Rodrigo Toro, Alfredo ceres \& Ricardo B. Maccioni. (1999). Inhibition of Tau phosphorylating protein kinase cdk5 prevents L-amyloid-induced neuronal death. FEBS Letters, Vol.459, pp.421-426, ISSN 0014-5793

Bennet BL, Sasaki DT, Murray BW, O'Leary EC, Sakata S T, Xu W. Leisten JC, Motiwala A, Pierce S, Satoh Y, Bhagwat SS, Manning AM \& Anderson DW. (Nov 2001) SP600125, an anthrapyrazolone inhibitor of Jun N-terminal kinase. Proc Natl Acad Sci USA, Vol.98, No.20, pp.13681-13686, ISSN 0027-8424

Büeler H. (Nov 2010). Mitochondrial dynamics, cell death and the pathogenesis of Parkinson's disease. Apoptosis, Vol.15, No.11, pp.1336-1353, ISSN 1360-8185

Buerger K, Ewers M, Pirttilä T, Zinkowski R, Alafuzoff I, Teipel SJ, DeBernardis J, Kerkman D, McCulloch C, Soininen H \& Hampel H.(Sep 2006). CSF phosphorylated tau protein correlates with neocortical neurofibrillary pathology in Alzheimer's disease. Brain, Vol.129, No.Pt 11, pp.3035-3041, ISSN 0006-8950

Chatterjee S, Zaman K, Ryu H, Conforto A \& Ratan RR.(Mar 2001) Sequence-selective DNA binding drugs mithramycin $\mathrm{A}$ and chromomycin A3 are potent inhibitors of neuronal apoptosis induced by oxidative stress and DNA damage in cortical neurons. Ann Neurol, Vol.49, No.3, pp.345-354, ISSN 0364-5134

Chung ES, Bok E, Sohn S, Lee YD, Baik HH \& Jin BK. (Jun 2010). GT1b-induced neurotoxicity is mediated by the Akt/GSK-3/Tau signaling pathway but not caspase-3 in mesencephalic dopaminergic neurons. BMC Neurosci, Vol.11, pp.74, ISSN 1471-2202. Available from:

http://www.biomedcentral.com/1471-2202/11/74

Duka T, Duka V, Joyce JN \& Sidhu A. (Apr 2009). Alpha-Synuclein contributes to GSK3beta-catalyzed Tau phosphorylation in Parkinson's disease models. FASEB J, Vol.23, No.9, (Sep 2009), pp.2820-30, ISSN 1742-464X

Duka T \& Sidhu A. (2006). The neurotoxin, MPP(+), induces hyperphosphorylation of Tau, in the presence of alpha-Synuclein, in SH-SY5Y neuroblastoma cells. Neurotox Res, Vol.10, No.1, pp.1-10, ISSN 1029-8428

Dutcher JP, Coletti D, Paietta E \& Wiernik PH. (May 1997). A pilot study of alpha-interferon and plicamycin for accelerated phase of chronic myeloid leukemia. Leuk Res, Vol.21, No.5, pp.375-380, Available from

http:/ /linkinghub.elsevier.com/retrieve/ pii/S0145212696001087.

Ethell DW \& Fei Q. (Mar 2009). Parkinson-linked genes and toxins that affect neuronal cell death through the Bcl-2 family. Antioxid Redox Signal, Vol.11, No.3, pp.529-540, ISSN 1523-0864

Evans DB, Rank KB, Bhattacharya K, Thomsen DR, Gurney ME \& Sharma SK.(2000). Tau phosphorylation at serine 396 and serine 404 by human recombinant tau protein 
kinase II inhibits tau's ability to promote microtubule assembly. J Biol Chem, Vol.275, pp.24977-24983, ISSN 0021-9258. doi: 10.1074/jbc.M000808200.

Ferrer I, Gomez-Isla T, Puig B, Freixes M, Ribé E, Dalfó E \& Avila J. (2005). Current advances on different kinases involved in Tau phosphorylation, and implications in Alzheimer's disease and Tauopathies. Curr Alzheimer Res, Vol.2, No.1, pp.3-18, ISSN 1567-2050

Ferrante RJ, Ryu H, Kubilus JK, D'Mello S, Sugars KL, Lee J, Lu P, Smith K, Browne S, Beal MF, Kristal BS, Stavrovskaya IG, Hewett S, Rubinsztein DC, Langley B \& Ratan RR. (Nov 2004). Chemotherapy for the Brain: The Antitumor Antibiotic Mithramycin Prolongs Survival in a Mouse Model of Huntington's Disease. J Neurosci, Vol.24, No.46, pp.10335-10342, ISSN 0270-6474

Gendron TF \& Petrucelli L. (Mar 2009). The role of tau in neurodegeneration. Mol Neurodegener. Vol.4, pp.13, Available from:

http://www.Molecularneuro- degeneration.com/content/4/1/13

Higuchi M, Lee VM \& Trojanowski JQ.(2002). Tau and axonopathy in neurodegenerative disorders (Review). Neuromol Med, Vol.2, No.2, pp.131-150, ISSN 1535-1084

Hou MH, Lu WJ, Lin HY \& Yuann JM. (Apr 2008). Studies of sequence-specific DNA binding, DNA cleavage, and topoisomerase I inhibition by the dimeric chromomycin A3 complexed with Fe(II). Biochemistry, Vol.47, No.20, pp.5493-5502, ISSN 0006-2960.

Ishizawa T, Mattila P, Davies P, Wang D \& Dickson DW. (2003). Colocalization of Tau and alpha-synuclein epitopes in Lewy bodies. J Neuropathol Exp Neurol, Vol.62, No.4, (Apr 2003), pp.389-397, ISSN 0022-3069

Karunakaran S, Saeed U, Mishra M, Valli RK, Joshi SD, Meka DP, Seth P \& Ravindranath V. (Nov 2008). Selective activation of p38 MAPK in dopaminergic neurons of substantia nigra leads to nuclear translocation of p53 in MPTP-treated mice. J Neurosci, Vol.28, No47, pp.12500-12509, ISSN 0270-6474

Kowall NW \& Kosik KS.(Nov 1987). Axonal disruption and aberrant localization of tau protein characterize the neuropil pathology of Alzheimer's disease. Ann Neurol, Vol.22, No.5, pp.639-643, ISSN 0364-5134

Lei P, Ayton S, Finkelstein DI, Adlard PA, Masters CL \& Bush AI. (Aug 2010). Tau protein: relevance to Parkinson's disease. Int J Biochem Cell Biol, Vol.42, No.11, pp.1775-1778, ISSN 1357-2725

Lloyd KG. (1977). CNS compensation to dopamine neuron loss in Parkinson's disease. Adv Exp Med Biol, Vol.90, pp.255-266, ISSN 0065-2598

Majee S \& Chakrabarti A. (1999). Membrane interaction of an antitumor antibiotic, mithramycin, with anionic phospholipid vesicles. Biochemical Pharmacology, Vol.57, No.9, pp.981-987, ISSN . doi:10.1016/S0006-2952(98)00374-8. PMID 10796068.

Marsden CD \& Parkes JD. (Feb 1977). Success and problems of long-term levodopa therapy in Parkinson's disease. Lancet, Vol.1, No.8007, pp.345-349, ISSN 0140-6736

Mattson MP. (Nov 2000). Apoptosis in neurodegenerative disorders (Review). Nat Rev Mol Cell Bio, Vol.1, No.2, pp.120-129, ISSN 1471-0072

Miller SC, Huang R, Sakamuru S, Shukla SJ, Attene-Ramos MS, Shinn P, Van Leer D, Leister W, Austin CP \& Xia M.( Jan 2010) Identification of known drugs that act as inhibitors of NF-kappaB signaling and their mechanism of action. Biochem Pharmacol, Vol.79, No.9, (May 2010), pp.1272-1280, ISSN 0006-2952 
Muntané G, Dalfó E, Martinez A \& Ferrer I. (Feb 2008). Phosphorylation of Tau and alphasynuclein in synaptic-enriched fractions of the frontal cortex in Alzheimer's disease, and in PD and related alpha-synucleinopathies. Neuroscience, Vol.152, No.4, (Apr 2008), pp.913-923, ISSN 0306-4522

Nagatsu T \& Sawada M. (2007). Biochemistry of postmortem brains in Parkinson's disease: historical overview and future prospects (Review). J Neural Transm-Supp, Vol.2007, No.72, pp.113-120, ISSN 0303-6995

Nishimura I, Yang Y \& Lu B.(2004). PAR-1 kinase plays an initiator role in a temporally ordered phosphorylation process that confers tau toxicity in Drosophila. Cell, Vol.116, pp.671-682, ISSN 0092-8674. doi: 10.1016/S0092-8674(04)00170-9.

Qureshi HY \& Paudel HK. (Dec 2010). Parkinsonian neurotoxin MPTP and alpha- synuclein mutations promote Tau protein phosphorylation at Ser262 and destabilize microtubule cytoskeleton in vitro. J Biol Chem, Vol.286, No.7, (Feb 2011), pp.50555068, ISSN 0021-9258

Reynolds CH, Garwood CJ, Wray S, Price C, Kellie S, Perera T, Zvelebil M, Yang A, Sheppard PW, Varndell IM, Hanger DP \& Anderton BH.(May 2008). Phosphorylation regulates tau interactions with Src homology 3 domains of phosphatidylinositol 3-kinase, phospholipase Cgamma1, Grb2, and Src family kinases. J Biol Chem, Vol.283, No.26, pp.18177-18186, ISSN 0021-9258

Rosol TJ \& Capen CC. (Oct 1987). The effect of low calcium diet, mithramycin, and dichlorodimethylene bisphosphonate on humoral hypercalcemia of malignancy in nude mice transplanted with the canine adenocarcinoma tumor line (CAC-8). J Bone Miner Res, Vol.2, No.5, pp.395-405, ISSN 0884-043

Rylander D, Parent M, O'Sullivan SS, Dovero S, Lees AJ, Bezard E, Descarries L \& Cenci MA. (2010). Maladaptive plasticity of serotonin axon terminals in levodopainduced dyskinesia. Ann Neurol, Vol.68, No.5, (Nov 2010), pp. 619-628, ISSN 03645134

Saporito MS, Thomas BA \& Scott RW. (Sep 2000). MPTP activates c-Jun NH (2)-terminal kinase (JNK) and its upstream regulatory kinase MKK4 in nigrostriatal neurons in vivo. J Neurochem, Vol.75, No.3, pp.1200-1208, ISSN 0022-3042

Sato S, Cerny RL, Buescher JL \& Ikezu T. (2006). Tau-tubulin kinase 1 (TTBK1), a neuronspecific Tau kinase candidate, is involved in Tau phosphorylation and aggregation. J Neurochem, Vol.98, No.5, (Sep 2006), pp.1573-1584, ISSN 0022-3042

Schönknecht P, Pantel J, Hunt A, Volkmann M, Buerger K, Hampel H \& Schröder J. (Mar 2003). Levels of total tau and tau protein phosphorylated at threonine 181 in patients with incipient and manifest Alzheimer's disease. Neurosci Lett, Vol.339, No.2, pp.172-174, ISSN 0304-3940

Sergeant N, Bretteville A, Hamdane M, Caillet-Boudin ML, Grognet P, Bombois S, Blum D, Delacourte A, Pasquier F, Vanmechelen E, Schraen-Maschke S \& Buée L.(Apr 2008). Biochemistry of Tau in Alzheimer's disease and related neurological disorders. Expert Rev Proteomics, Vol.5, No.2, pp.207-224, ISSN 1478-9450

Voisine C, Varma H, Walker N, Bates EA, Stockwell BR, et al (2007) Identification of Potential Therapeutic Drugs for Huntington's Disease using Caenorhabditis elegans. In: PLoS ONE, 06,06,2007, Available from:

http://www.plosone.org/ article/info\%3Adoi\%2F10.1371\%2Fjournal.pone.0000- 504 
Wang WY, Li MT, Rao JJ \& Zhu NM. (2010). The protective action of chromomycin on dopaminergic neurons. Chinese Pharmacological Bulletin, Vol.26, No.4, pp.522-526, ISSN 1001-1978

Wang W, Shi L, Xie Y, Ma C, Li W, Su X, Huang S, Chen R, Zhu Z, Mao Z, Han Y\& Li M. (Feb 2004). SP600125, a new JNK inhibitor, protects dopaminergic neurons in the MPTP model of PD. Neurosci Res, Vol.48, No.2, pp.195-202, ISSN 0168-0102

Wang W, Yang Y, Ying C, Li W, Ruan H, Zhu X, You Y, Han Y, Chen R, Wang Y \& Li M. (Apr 2007). Inhibition of GSK-3beta protects dopaminergic neurons from MPTP toxicity. Neuropharmacology, Vol.52, No.8, (Jun 2007), pp. 1678-1684, ISSN 0028-3908

Yuan J \& Yankner BA.(Oct 2000). Apoptosis in the nervous system (Review). Nature, Vol.407, No.6805, pp.802-809, ISSN 0028-0836

Zheng YL, Kesavapany S, Gravell M, Hamilton RS, Schubert M, Amin N, Albers W, Grant P \& Pant HC. (2005). A Cdk5 inhibitory peptide reduces Tau hyperphosphorylation and apoptosis in neurons. EMBO l, Vol.24, pp.209-220, ISSN 0261-4189 


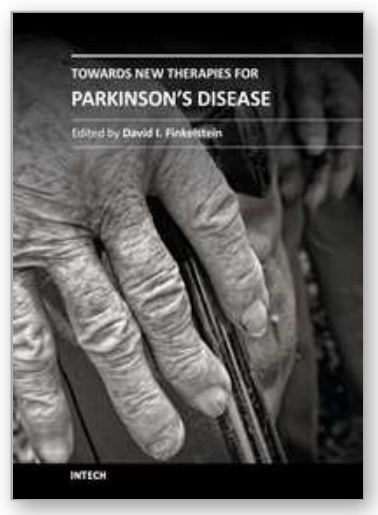

\section{Towards New Therapies for Parkinson's Disease}

Edited by Prof. David Finkelstein

ISBN 978-953-307-463-4

Hard cover, 396 pages

Publisher InTech

Published online 02, November, 2011

Published in print edition November, 2011

Parkinson's disease (PD) is characterised clinically by various non-motor and progressive motor symptoms, pathologically by loss of dopamine producing cells and intraneuronal cytoplasmic inclusions composed primarily of ?-synuclein. By the time a patient first presents with symptoms of Parkinson's disease at the clinic, a significant proportion of the cells in the substantia nigra have already been destroyed. This degeneration progresses despite the current therapies until the cell loss is so great that the quality of normal life is compromised. The dopamine precursor levodopa is the most valuable drug currently available for the treatment of PD. However for most PD patients, the optimal clinical benefit from levodopa decreases around five to six years of treatment. The aim of the chapters of this book is to work towards an understanding in the mechanisms of degeneration and to develop disease modifying therapies.

\section{How to reference}

In order to correctly reference this scholarly work, feel free to copy and paste the following:

Wang Wenya (2011). Inhibition of Tau Phosphorylation as a Potential Strategy in Treatment of Parkinson's Disease, Towards New Therapies for Parkinson's Disease, Prof. David Finkelstein (Ed.), ISBN: 978-953-307463-4, InTech, Available from: http://www.intechopen.com/books/towards-new-therapies-for-parkinson-sdisease/inhibition-of-tau-phosphorylation-as-a-potential-strategy-in-treatment-of-parkinson-s-disease

\section{INTECH}

open science | open minds

\author{
InTech Europe \\ University Campus STeP Ri \\ Slavka Krautzeka 83/A \\ 51000 Rijeka, Croatia \\ Phone: +385 (51) 770447 \\ Fax: +385 (51) 686166 \\ www.intechopen.com
}

\author{
InTech China \\ Unit 405, Office Block, Hotel Equatorial Shanghai \\ No.65, Yan An Road (West), Shanghai, 200040, China \\ 中国上海市延安西路65号上海国际贵都大饭店办公楼 405 单元 \\ Phone: +86-21-62489820 \\ Fax: +86-21-62489821
}


(C) 2011 The Author(s). Licensee IntechOpen. This is an open access article distributed under the terms of the Creative Commons Attribution 3.0 License, which permits unrestricted use, distribution, and reproduction in any medium, provided the original work is properly cited. 